From Full Dusk to Full Tusk:

Reimagining the "Dusky Maiden"

through the Visual Arts

A Marata Tamaira

You can't depend on your eyes when your imagination is out of focus.

MARK TWAIN, A Connecticut Yankee in King Arthur's Court ${ }^{1}$

\begin{abstract}
As encounters between Western explorers and Pacific Islanders intensified during the mid-eighteenth century, Euro-American audiences were introduced to the region from afar through the travel narratives of their voyaging countrymen and the vivid visual imagery of artists who portrayed Polynesia as an idyllic haven, populated by "noble savages" existing against a backdrop of white-sand beaches and tropical mountain ranges (Smith I960; I992). A central component of these early romantic constructions was the ubiquitous image of the sexually receptive and alluring Polynesian maiden-an image that was deployed to good effect in the works of artists such as William Hodges, John Webber, and later Paul Gauguin (Jolly 1997; Smith I960; Mathews 200I; Bindman 2004). As Samoan filmmaker Sima Urale revealed in her documentary Velvet Dreams, the black velvet paintings of the "kitsch" I950s era continued the tradition of sexualizing and eroticizing the Polynesian female form through titillating visual representations of bare-breasted, nubile Polynesian wāhine (women), which functioned as soft porn for art connoisseurs (Urale 1997). Indeed, the visual arts have operated as a vehicle by which the "dusky maiden" motif has been faithfully transported through history to the current day.
\end{abstract}

In the contemporary period, female Polynesian artists have sought to challenge, subvert, reimagine, and reimage the dusky maiden in order to

The Contemporary Pacific, Volume 22, Number I, I-35

(C) 2010 by University of Hawai'i Press 
open up alternative spaces in which to reread this centuries-old icon. This article begins with a brief foray into Polynesian mythology in order to elucidate the mana (prestige, power, potency) associated with women in the Polynesian worldview. Due to restrictions of length, I have chosen to limit my angle of vision to Hawai'i, Aotearoa (New Zealand), Sāmoa, and Tahiti for two reasons: first, these places tend to figure prominently in peoples' minds when thinking of Polynesia, and second, they have been the focus of intense visual representation over the last three centuries. Thus, while these four areas do not by any means constitute Polynesia as a whole, they nevertheless serve as important touchstones for discussing and thinking about the types of visual representations that have been produced in the region.

In the second section, I interrogate early European depictions of Polynesian women, which I argue have served to conceal feminine power in the region. I focus on two paintings in particular-Tahiti Revisited (aka Vaitepiha Bay) by William Hodges and Poedua by John Webber-both of which were rendered in such a way as to objectify and sexualize the Polynesian female form and were circulated widely in Europe during the late eighteenth century (Jolly I997, I02). While it should be understood that Hodges and Webber were by no means the only artists to depict Polynesian women during the nascent period of contact between Islanders and foreigners, ${ }^{2}$ these two men constituted the first wave of academy-trained artists to be included on voyages of exploration into the Pacific. In many ways, then, Hodges and Webber paved the way for subsequent expressions of Western representational power in the region.

In the third part of the article I explore the creative endeavors of three contemporary female Polynesian artists: Rosanna Raymond, Shigeyuki Kihara, and Sue Pearson, all of whom consciously seek to reinscribe the stereotype of the dusky maiden with new and empowering meaning. While I acknowledge that there are many other female Polynesian artists who are engaged in disrupting the dusky maiden trope, my interest in these three women lies in the fact that the first two (Raymond and Kihara) both utilize their own bodies to challenge Western visual representations, and Pearson-who is a direct descendant of the Tahitian women who traveled on the Bounty to Pitcairn Island-offers a critical counterpoint to the stereotypes of her ancestresses that have been propelled into popular imagination.

Although this is a research-based article, I believe strongly that fiction can help illuminate many of the issues considered herein. As Greg Dening 
put it (I997, 42I), "Imagination is the ability to see those fine-lined and faint webs of significance"-lines and webs we may not be able to see with our physical eyes. While I am aware that my blending of academic scholarship and creative prose may draw some criticism, I would like to point out that I am hardly venturing into unchartered waters. Indeed, one of Aotearoa/New Zealand's most celebrated Māori scholars, Sir Peter Buck (Te Rangi Hiroa) included a dream he had while conducting research for the Marquesas Islands chapter in his seminal work, Vikings of the Sunrise (1938, I 58-162). ${ }^{3}$ He wrote: “After pouring over Linton's plan of the assembly place of Nanauhi, in the Hatiheu Valley of Nukuhiva, $I$ dreamed a dream compounded of what I had read and what I felt" (Buck I938, I 59; emphasis added). Here, Buck not only relied on conventional standards of scholarship to interpret the settling of the Islands but also drew on his own sleep-state imaginings of the place and the people. Thus, in the final section of this article I deploy the medium of creative writing to bring together what I have read and felt during my own exploration of the dusky maiden.

The phases of this article are designed to correspond loosely with the varying states of change that feminine power has undergone in Polynesia, beginning in the ancestral past, moving through the period of Western contact and colonization, and ending with the postcolonial present. As I hope to reveal, representations of Polynesian women, whether rendered in the past or the present, are laden with multiple and complex meanings that constantly shift and slide between the binary opposites of sexual vulnerability and potent danger (see Jolly I997). However, rather than focus on the diametric opposition of these states of being, my intent here is to fathom the liminal realm, the ambiguous interstices in which the dusky maiden, of her own volition, shifts shape and direction.

\section{Female Gods}

The Polynesian pantheon is replete with strong female figures. The oral traditions, songs, and chants that derive from the numerous cultures within Polynesia tell of goddesses who had the power to bestow life and withdraw it, who set out on daring seafaring odysseys to found new islands in the vast and liquid reaches of Oceania, and who led ancient armies into battle. Indeed, in the Polynesian worldview, goddesses possessed tremendous mana (Yates-Smith I998; Kame'eleihiwa I999; Meleiseā I999). The Hawaiian creation chant Kumulipo offers salient insight into the sig- 
nificance of the female principle in Hawaiian society. In the chant, life begins in Pō, the female night. Hawaiian scholar Lilikalā Kame'eleihiwa's translation of a section of the chant reveals the generative power of Pō (1999, 2):

At the beginning of the deep darkness

At the beginning of the night, only night

In the unfathomable dark blue darkness

In the darkness of the sun

In the endless night

It was entirely night; the night gave birth.

As Kame'eleihiwa remarked, Pō is "the ancestor of all Akua; she is the source of life, of divinity, and of ancestral wisdom" (1999, 3; italics in original). But where life springs forth, death also crouches in the shadows. The sexual organs of the Polynesian goddesses not only operated as a secret place where human life was nurtured and released into Te Ao Mārama, the world of light, but they also served as a crushing vise to extinguish life's breath. Māori scholar Aroha Yates-Smith has observed that, "Fertility and death . . . are both encompassed in women's sexual organs, making them extremely powerful, even threatening" (I998, I 55). Indeed, in Māori mythology the demigod Maui's final and fateful exploit offers a cautionary tale to those who would underestimate feminine power. In an attempt to obtain immortality for humankind, Maui devised a plan to slay his ancestress, Hine-nui-te-Pō, the Great Lady of the Night, by entering through her puta (vagina) and exiting through her mouth while she slept. However, just as Maui's head entered her sleeping form, one of his companions, a small Pīwaiwaka (fantail [a species of bird]), laughed out loud and woke the slumbering goddess. Intuiting Maui's treacherous intentions, Hine-nui-te-Pō squeezed her legs tightly together and crushed the famous trickster to death (Pomare and Cowan I987, I7-18). Other strong female figures in Māori mythology existed in the form of taniwha, supernatural beings who inhabited the sea and inland waterways, and who were usually attached as guardians to specific iwi (tribes). Famous female taniwha included Hine-kōrako, who, according to legend, saved a canoeload of people from being swept over Te Rēinga Falls, and Āraiteuru, who is credited with protecting the people of the Hokianga region (Orbell I999).

Other prominent female figures in the Polynesian pantheon include the Hawaiian goddesses, the most dynamic of them being Pele, "the queen 
of fire and goddess of volcanoes" (Kalākaua I990, I39). Accompanied by her younger sister Hi'iaka and several brothers, Pele set out across the ocean from her ancestral homeland of Kahiki to settle in the Hawaiian archipelago (Beckwith I976). Hawaiian mele (songs), oli (chants), and mo'olelo (stories) are replete with Pele's exploits, many of which are characterized by her fiery temper and unbridled jealousy. In one account, Pele sent Hi'iaka to retrieve Pele's husband Lohi'au, a young chief from Kaua' $i$, and return him to the goddess's residence on the island of Hawai' $i$. Pele gave Hi'iaka forty days in which to complete the task. However, due to several mishaps, the excursion took longer than expected. Impatient with Hi'iaka's extended absence, and convinced that she and Lohi'au had engaged in intimate relations during the journey, when the innocent pair finally did arrive on Hawai'i Island, Pele consumed her lover's body with the searing heat of her jealous rage (Beckwith 1976, I73-I77). As should be clear from the narrative, Pele is by no means a goddess to be taken lightly. Indeed, the Hawaiian monarch King David Kalākaua wrote of Pele, "her bright eyes and queenly presence commanded the respect and homage of all who approached her" (I990, I4I).

While the charismatic Pele offers a clear example of the potency of the female principle in the Hawaiian worldview, countless other Hawaiian goddesses also operate as powerful agents in their own right. For instance, the two sisters, Kapo'ulakinna'u and Kalaipāhoa, possess the power over life and death, and Haumeanuīaiwaīwa (great Haumea of the divine mystery) is credited with retaining a triumvirate of occupations as "goddess of childbirth, politics, and war" (Kame'eleihiwa 1999, 28). Of course, these goddesses represent but a few of the multitude of female deities observed in Hawaiian culture.

Another famous goddess, Nāfanua, is credited in Sāmoa for her abilities in war (Steubel I976; Schoeffel I987; Meleiseā I999). Nāfanua was the child of Saveasi'uleo, a deity of Pulotu (the Underworld), and his wife Tilafaigā. When Tilafaiga aave birth to a blood clot, she buried it in the earth. Within the nurturing embrace of the soil the unformed fetus began to take shape and eventually emerged as an adult woman, Nāfanua (meaning "hidden in the earth"). Legend has it that during Nāfanua's time, the eastern districts of Savai'i had defeated the people of the west. On learning of the atrocious conditions under which the western districts were being forced to live, Nāfanua set about organizing a mighty army to liberate them. Once prepared, Nāfanua led her fighting forces into battle against the eastern oppressors and annihilated them. After the fierce engagement, 
Nāfanua conferred political authority on the chiefs of the western districts, thus ushering in a new political order. Samoan scholar Mālama Meleiseā has pointed out that there still remains a place in western Savai' $i$ referred to as "the meeting ground of shame." The name commemorates the moment in the battle when the eastern forces realized to their dismay that the victor, Nāfanua, was in fact a woman, as disclosed "when her cloak blew back, revealing her breasts" (Meleiseā I999, 56).

It is critical to point out that the goddesses mentioned above, as well as the host of other female deities associated with the Polynesian pantheon, are not simply supernatural heroines consigned to the swirling mists of a primordial past, but that they constitute actual ancestors, who are genealogically linked to their female descendants. As Kame'eleihiwa has asserted of the relationship between Hawaiian women and the Hawaiian goddesses: "It is the female Akua that empower Hawaiian women. They are our ancestors; they are our inspiration; they live in us" (I999, 3). To extend that statement, all Polynesian women, whether they are from Hawai'i, Aotearoa, Sāmoa, or elsewhere in Polynesia, may be seen as being imprinted with the same potent material as their respective goddesses - powerful entities who are reborn in each succeeding generation of women (Kame'eleihiwa 1999).

In this section I have stressed the power and significance of women in the Polynesian pantheon. The female gods were respected, loved, and, yes, even feared. In the next section I discuss how, during the period of contact, Western artists literally and figuratively painted over the agency and power of Polynesian women by representing them not as the genealogical descendants of powerful goddesses, but as exotic, vulnerable maidens.

\section{The Concealment of Female Power}

Naked and smiling, every nymph we see, Like Eve unapron'd, 'ere she robb'd the tree Immodest words are spoke without offence, And want of decency shews innocence.

JOHN COURTENAY, Epistle (Moral and Philosophical) from an Officer at Otaheite ${ }^{4}$

\section{Retracing Early European Narratives}

As Europeans expanded into the wider world during the latter part of the eighteenth and the early nineteenth century, the gap that separated the West from the distant realm of the Pacific began to close rapidly. Early 
visitors to Polynesia, such as French navigator Louis Antoine de Bougainville, ${ }^{5}$ were heavily influenced by the utopian views of philosopher Jean-Jacques Rousseau, who idealized "primitive" societies as living in a Golden Age (Smith I960, 25). Here, “'natural man' was healthy, happy, and free," rather than fettered by the chains of industrialized civilization (Barnard 2000, 2I). In an era of Enlightenment philosophy and Western wanderlust, the romantic image of the "noble savage" loomed large in the European imagination, and grew even larger when European explorers and travelers returned home to relay their experience of the South Seasin particular their encounters with South Seas women. Bougainville's narratives served as kindling to fuel the furnace of the Western imaginary. Bougainville gave a riveting account of the greeting he and his crewmen received as they arrived in Tahiti in I769: "All these people came crying out tayo, which means friend, and gave a thousand signs of friendship ... the periaguas [canoes] were full of females ... most of these fair females [being] naked" (Bougainville 1967, 218). ${ }^{6}$ Bougainville relays that at the sight of so many "fair females" in their midst, it was difficult for him and his commanders to control not only the men, but themselves as well: "At last our cares succeeded in keeping these bewitched fellows in order, though it was no less difficult to keep the command of ourselves" (Bougainville I967, 219).

The trope of Tahiti (and, indeed other locations in Polynesia) as an Edenic wonderland also gained purchase in the cognitive folds of the Western imagination through Bougainville's fantastical accounts of the island's bountiful landscape. After several jaunts around the island, Bougainville wrote: "I thought I was transported into the garden of Eden, we crossed a turf, covered in fine fruit-trees, and intersected by little rivulets, which keep up a pleasant coolness in the air" $(1967,228)$. The vision of Eden that Bougainville promulgated did not end with the island's tropical flora and picturesque terrain; it also included the female inhabitants-after all, what is Eden without Eve? Sharing a penchant for the classical past with so many of his Western compatriots, Bougainville likened Tahitian women to the Greek goddess Venus. Of one young woman he wrote: "The girl carelessly dropt a cloth, which covered her, and appeared to the eyes of all beholders, such as Venus shewed herself to the Phrygian shepherd, having, indeed, the celestial form of that goddess" (Bougainville 1967, 219). As Miriam Kahn stated, "When Bougainville returned to Europe with stories of beautiful and uninhibited women, visions of sexual abandon swept like wildfire through Paris and London" (2003, 3 IO). 
Other early accounts of Tahitian women came from travelers such as Dr John Hawkesworth, who was given the onerous task of translating and publishing the Pacific discoveries of several well-known explorers, most notably Captain James Cook. Hawkesworth provided titillating reports of Queen Purea (referred to as Oberea by the British), the wife of Amo, an ari'i nui (high-ranking chief) of Tahiti (Dening 2000). Indeed, as Patty O'Brien has argued, Purea constitutes "the first popular female figure in Pacific imperial narratives" (2006, I9). The queen gained infamy in England not only for her scandalous love affair with the dashing young botanist Joseph Banks, but for her orchestration of a public copulation involving a young Tahitian girl, and watching while a young Tahitian girl danced naked in front of Banks. Purea also gained considerable attention for her "pinked bum [tattooed buttocks]" (Dening I992, 266). An anomaly in the prudish sensibilities of the British public, Purea's tattooed buttocks became the source of much satirical wit and farcical writings. One poet wrote: "Vain Oberea will in vain beseech / And to the bawdy winds betray her painted breech" (quoted in Dening 1992, 267).

Ensnared by the imperial gaze, Purea became popularized as a succubus of sorts, a "hotty-tooty queen" with loose morals (Dening I992, 267). She was even immortalized as "Oberea the Enchantress" in a pantomime entitled Omai or a Trip Round the World, which was performed at Covent Garden, London, in I785. A powerful political exponent in her own right, in the pantomime Purea was summarily reduced to a figure of fascination-an exotic, erotic Other whose "menacing sorcery" had to be stamped out (Dening 2000, I27).

The breathless accounts that Bougainville and other travelers gave of Polynesian women were not the only depictions that simultaneously tickled and troubled the minds of an impressionable European public. They worked in tandem with the visual texts that were being produced by artists who accompanied the various expeditions into the Pacific. These artists literally and figuratively painted Polynesia as a sexual Mecca where sexstarved sailors and aristocratic gentlemen alike could satisfy their carnal itchings. Two artists who popularized the visual trope of the exotic dusky maiden were William Hodges (I774-I797) and John Webber (I752I793), who served on Cook's second and third expeditions, respectively.

Western Visual Representations: Painting the Polynesian Canvas

As the previous section suggests, Tahiti, more than any other place in Polynesia, has had a powerful pull on the Western imagination. As Kahn 
noted, the "myth of Tahiti is like a pebble that centuries ago was tossed into the water, rippling far and wide, lapping at distant shores, and piquing imaginations around the world" (2003, 309). William Hodges's 1776 oil painting Tahiti Revisited (figure I) - which depicts the first anchorage at Vaitepiha Bay, Tahiti, during Captain James Cook's second voyage through the Pacific (I772-I775) - constitutes one among many "ripples" that lapped on the shore of Western imaginations during the eighteenth century.

In keeping with Hodges's painterly style, Tahiti Revisited features "light-filled skies," and hues of soft pinks and blues (Beaglehole I969, xiii). With its backdrop of majestic mountain ranges reaching up to a luminous sky, and coconut trees swaying gently in the breeze, the painting evokes a romantic vision of Tahiti as a tropical paradise-indeed, the " New Cythera" of the Pacific (Kahn 2003, 3 IO). ${ }^{7}$

However, it is not only Tahiti's landscape in Tabiti Revisited that is aestheticized. Three voluptuous, nude female figures are prominent in the foreground. Two of the women languish on a rocky outcrop under the silent gaze of a Tahitian ti'i (god image), while the other floats, face-tosky in a river nearby; in the distance a corpse lies draped in a shroud atop a tupapapa'u (elevated platform). In Imagining the Pacific: In the Wake of the Cook Voyages, art historian Bernard Smith noted that Hodges was intent on constructing, through his paintings, an image of Tahiti as "a tropical paradise of sunshine and sensuous, liberated women-even more beautiful, more tempting than Italy" (Smith I992, I32). However, in order to make Tahiti Revisited more palatable for a prudish patrician public back home, Hodges included the Tahitian god image and the mortuary platform as backdrops in the hope that "these motifs of death and transience might possibly lull the anxieties aroused by such exotica [that is, the sexually charged forms of the nude women]" (Smith I992, I3I).

Margaret Jolly's reading of the painting offers an alternate perspective. She has suggested that, in fact, the motifs are rendered in a "voyeuristic manner" that nurtures in the Western imagination the notion of Polynesian women in general and Tahitian women in particular as not only sexually provocative, but threatening as well-albeit in a tantalizing way ( 1997, I02). Jolly went on to assert, "Perhaps such marks of an inscrutable difference-the tattoo [as revealed on the buttocks of one woman], the statue, even the shrouded corpse-might rather enhance desire, combining the half-revealed bodies of beautiful women with other elements which render them remote and dangerous" (I997, I02; emphasis added). Thus, 


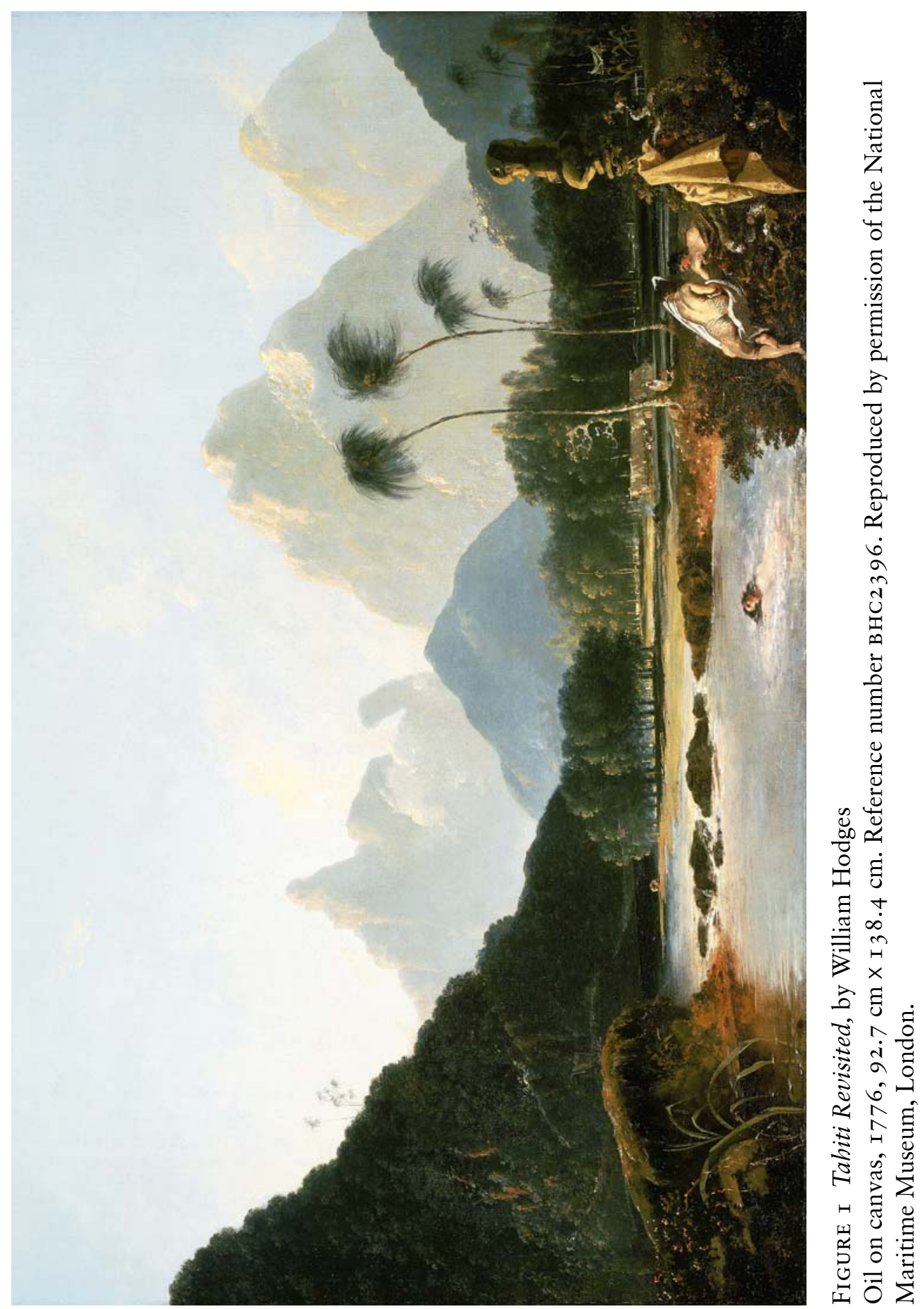


the simultaneous portrayal of Polynesian women as sexually receptive as well as distant and dangerous (as signified by the tattoos inscribed on their bodies), served to intensify rather than curb their exotic and erotic appeal in the Western imagination (Jolly I997).

English artist John Webber accompanied Cook on his third expedition (I776-I780) through the Pacific in search of the Northwest Passage (MacLean 1972). While Cook's ship, the HMs Discovery, was anchored in Ra'iatea, two seamen, enamored by the island lifestyle and, no doubt, by the women, "jumped ship" and deserted. As a tactical measure to retrieve the two men, Cook took four hostages: Orio (an ari'i or chief of Ra'iatea), his daughter Poedua, ${ }^{8}$ his son Teura, and Poedua's husband, Moetua (Beaglehole I967b, 1076). The captives were held for four days-25 to 29 November 1777 - until the errant seamen returned to their posts, after which the four were released. As O'Brien stated, it is during her incarceration on Cook's ship that "Poedua was immortalized by John Webber as the superlative visual embodiment of the South Sea muse" (2006, 85).

John Webber's I 777 portrait Poedua (figure 2) shows the young woman in a classical pose that is reminiscent of the life-size marble sculpture Medici Venus, underscoring, yet again, the Enlightenment proclivity for the Greek classics (see Smith I960, 26).

Poedua's left arm (tattooed) gracefully crosses her body to rest near her right hip, while in her right hand she holds a fly whisk, a symbol of her chiefly status. Her gaze is benign, passive even; the corners of her mouth curl up into a wistful smile. Two gardenias are tucked behind each ear; her dark, slightly curly hair tumbles onto her bare shoulders. White fabric (possibly tapa or Western cloth) covers her middle and lower extremities, while her adolescent breasts are exposed to the viewer. The outline of her body beneath the cloth indicates a full, curvaceous figure. The painting is replete with a backdrop of lush, tropical foliage, the ubiquitous signifier of exotic climes. Portraits of Polynesian women such as this can be readily connected to what might best be described as "colonial spin doctoring." Jolly has asserted that colonial powers sought to obscure the violence that was occurring between foreign interlopers, such as Cook, and indigenous Island inhabitants, by creating an image of what Bernard Smith referred to as "a pacific Pacific" through the visual arts (Jolly I997; Smith I992, 2 IO). Jolly went on to state that, "The image of Poedua is an intrinsic part of this process, of the aestheticization of the violence of Cook's voyages" (1997, I04). Here, the truth of Poedua's kidnapping is covered over by Webber's visual representation, which implies an altogether different real- 


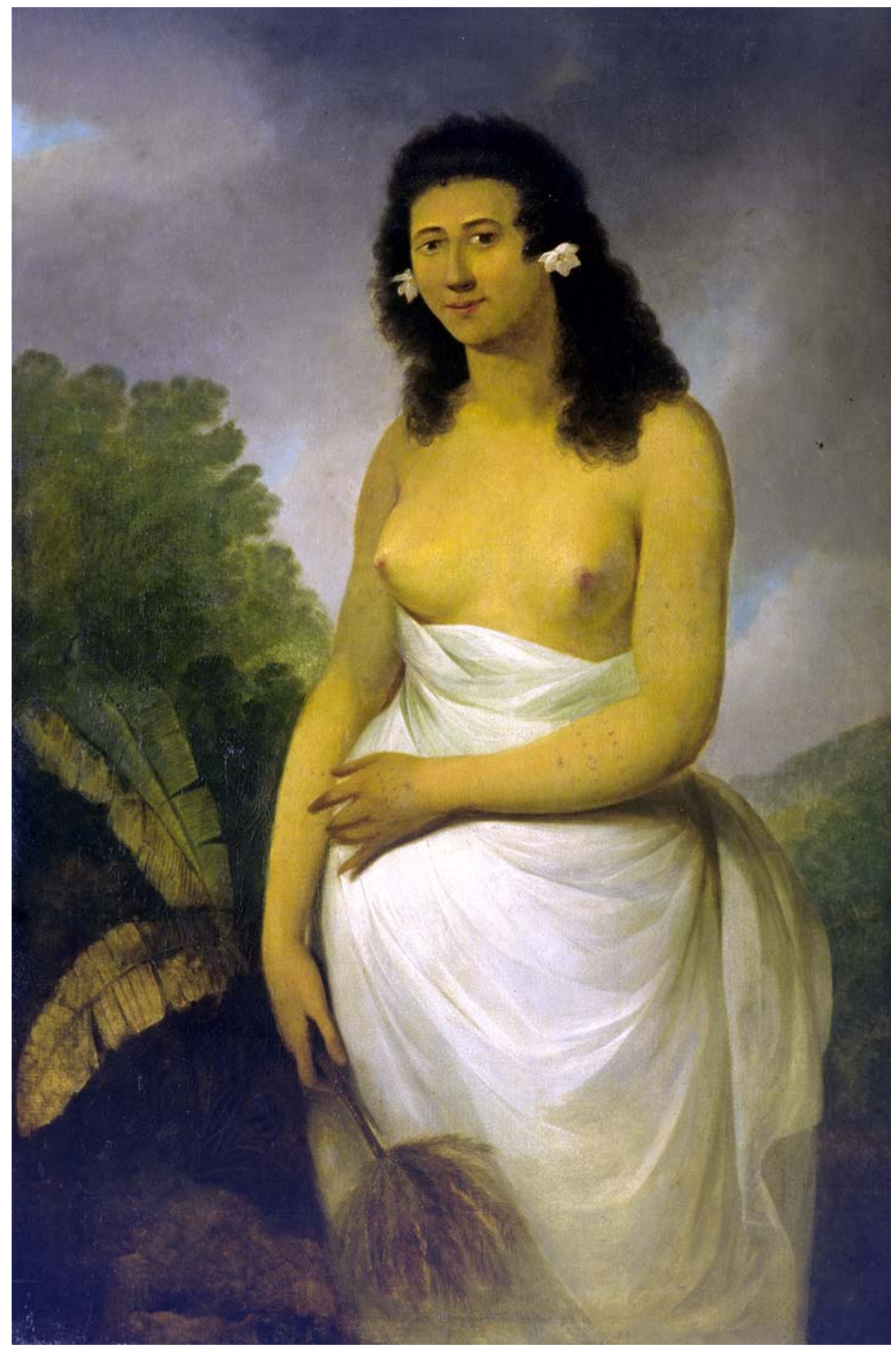

Figure 2 A Portrait of Poedua, by John Webber Oil on canvas, I782, I $44.7 \mathrm{~cm} \times 93.5 \mathrm{~cm}$. Rex Nan Kivell Collection. Reference number PIC T520 NK 5 I92. Reproduced by permission of the National Library of Australia, Sydney. 
ity, one in which Poedua is a willing participant rather than a captive. But, as the epigram at the beginning of this article cautions, we cannot depend on our eyes. According to David Samwell, the Discovery's surgeon, Poedua and members of her family had in fact been tricked into boarding Cook's ship, through the promise of "Knives, beads \& other Things they had been asking him for on shore" (Beaglehole 1967b, 1076). Once on board and informed that they were to be detained until all of the deserters were returned, Poedua fell into inconsolable weeping. Samwell noted, "The Indians finding themselves thus caught in a Snare fell a crying, especially the beautiful Poiedooa [Poedua] who was not to be pacified" (Beaglehole 1967b, 1076). While the aggression shown toward Poedua and her kin at the moment of their kidnapping and during their captivity on Cook's ship does not seem to have been of a physically abusive nature, the psychic and emotional violence that was wielded had an equally negative impact. The force of Poedua's kidnapping not only affected the young woman, but also the women from whom she was taken. In his journal entry dated 26 November I777, Cook reported, "The Confinement of Poedua the Chiefs Daughter was generally lamented ... the Women seemed to vie with each other in the loudness of their lamentations and there were many bloody heads on the occasion" (Beaglehole r967a, 248). The "bloody heads" alluded to by Cook were the result of the women cutting themselves with shark's teeth to indicate their grief at the loss of their ari'i. Yet such grief-both that of the women on shore and of Poedua incarcerated on the Discovery - is erased through the sweep of the artist's brush. Even the lush backdrop painted behind Poedua is a ruse, concealing as it does the fact that when the painting was rendered she was not on her native soil but captive on a foreign vessel. Lisa Taouma, a Pacific Islander academic of Samoan descent, has noted the connection between visual representations of the female Polynesian body and colonial aggression: "The 'dusky maiden' functions as a metaphor for the colonisation of the Pacific in that she, like our social, economic and religious structures, was shaped to fit a colonial agenda. She can be seen as a symbolic representation for the land itself - a guiding beacon to its fecund and fertile depths. . . The image of the 'dusky maiden' is also in this way an image of domestication, of the tamed 'noble savage" (2004, 37, 40).

But was Poedua simply a victim of circumstance, a pawn used in Cook's attempt to recoup his wayward men, or was she a woman of deeper substance and agency? Looking at her portrait it is difficult to determinethe "harmonious image of tropical tranquility" that Webber inscribed in Poedua's image serves to obfuscate rather than illuminate who she might 
really have been (O'Brien 2006, 84). As O'Brien has written, she is for all intents and purposes "the epitome of the imagined Pacific, being 'young, feminine, desirable and vulnerable" (2006, 82). In many ways, then, Poedua has twice been made captive: first on Cook's ship, and second within a congealed matrix of centuries-old oil and pigment.

Other Polynesian women were drawn into the Western scheme of exoticization through such artistic mediums as photography. Early black-andwhite photographs of Māori maidens with titles such as "A Maori Belle" were disseminated in the form of postcards in New Zealand and abroad (King 1996), while sepia portraits of "Hawaiian Beauties," with their faraway gaze and lei-bedecked hair advertised the allure of the Hawaiian Islands to the leisure class. In a similar way, the early I90os French photographer Lucien Gauthier created a series of postcards under the provocative title "Beautés Polynésiennes" (Polynesian beauties), which depicted Tahitian women in various alluring poses (Kahn 2003). Several decades later the velvet paintings of the I950s and I960s suspended the image of the doe-eyed, sexually provocative Polynesian "Velvet Lady" like a bright orb in the minds of the "kitsch" generation, inspiring an almost cultish following of velvet-art enthusiasts and collectors that continues even today (see Urale 1997).

The systematic way in which the Polynesian female form has been objectified and exploited by European artists and thrust into the minds of Western audiences can be interrogated alongside literary theorist Edward Said's 1978 treatise, Orientalism. In this early and critical contribution to postcolonial writings, Said argued that, "the Orient is not an inert fact of nature. It is not merely there" (1994, 4; emphasis in original); rather, it is a cognitive construct, "an idea that has a history and a tradition of thought, imagery, and vocabulary that have given it reality and presence in and for the West" (Said 1994, 5; emphasis added). That is, knowledge of "the Orient," and, as I argue, Polynesia, has been refracted through a distorted lens-a lens that has been systematically shaped by Westerners for the purpose of "dominating, restructuring, and having authority over" it (Said I994, 3). Visual representations have been a necessary and significant element in these ideological constructions. As with the paintings of famous Orientalist painters such as Eugene Delacroix, Jean-Leon Gerome, and Jean-Auguste-Dominique Ingres, the works of Webber and Hodgesas well as other Western artists-constitute visual strands in a Western narrative that tells of colonial desire and subjugation in Polynesia.

In discussing America's imperial agenda in the Pacific, Paul Lyons 
deployed the term Pacificism in place of Orientalism to describe the process "through which colonialism grounds its claims and claims its grounds" (2006, I 2). And such claims include not only geographical space, but as Heather Leigh Waldroup has pointed out, "the bodies within that space" $(2004,30)$. Waldroup uses the term Polynesianism to characterize the specific process by which the West has imagined and, indeed, imaged Polynesia and the indigenous female bodies that inhabit the region. As Waldroup wrote, "Pleasure is a defining aspect of Polynesianism: the exoticism, mystery and intimacy afforded by such images accounts for their primacy in popular spaces" $(2004,33)$. However, as is the case with any image, meaning is both contestable and malleable. In a brief but important paper titled "Colonialism, Orientalism, and the Canon" (I996), Zeynep Çelik argued that as oppressed communities begin to assert their voices above the hubbub of Orientalist discourse (or, as in this case, Polynesianist discourse), meaning is both unmade and remade. As she stated: "The voice of certain alterities, kept silent by the valorized culture, begins to enter the dialogue, thereby complicating the meanings and contextual fabrics of the art objects [read visual representations] and disrupting inherited historiographic legacies" (Çelik I996, 205). Thus, over the last several years, contemporary Polynesian female artists have been actively complicating and disrupting the received visual representations of a Polynesianist canon by reappropriating the dusky maiden motif and reinscribing it with fresh and empowering substance.

\section{Female Power: Re-Presenting the "Dusky Maiden”}

\section{Rosanna Raymond}

Rosanna Raymond is a New Zealand-born Pacific Islander of Samoan and Pākehā descent who has worked in a range of creative media, including costume design, poetry, dance, jewelry making, and multimedia performance art. She was a founding member of Pasifika, a fashion show that catapulted Pacific Islanders and their styles-both traditional and contemporary-into the fashion arena in the I990s, and she is a member of the Pacific Sisters, an art collective created in 1992 by Pacific Islander and Māori women including Suzanne Tamaki, Jeanine Clarkin, Ani O’Neill, Fiona Wall, and Niwhai Tupaea (Colchester 2003; Mallon and Pereira 2002). The collective, as Raymond stated in an interview, was instrumental in opening a critical "space where we [the members] could all be our Polynesian selves” (Yamauchi 2005). In 2006 Raymond worked as co- 
curator and creative director for the "Pasifika Styles" exhibition, which was held at the Cambridge Museum of Archaeology and Anthropology, in Britain, where she and her family now reside. The exhibition showcased the works of thirty New Zealand-based Pacific Islander and Māori artists, including the art creations of Raymond and Shigeyuki Kihara (discussed later). Raymond was clear about the intent of the exhibition: "We are committed to creating a UK platform for Pacific-born artists to 'speak back' to European audiences through their art, in their own words and on their own terms" (University of Cambridge 2007).

The notion of "speaking back" to Western representations of Polynesian women is a salient feature of Raymond's work. Her early career as a catwalk model in Europe provided Raymond with critical insight into the pervasiveness of the dusky maiden stereotype. Recalling her experience, she stated, "Papapalagi (foreigners) have pretty fixed ideas of Polynesian women-they have an image that they can picture in their mind's eye that seems to overshadow everything they see.... no matter what I said or did, people still labeled me as exotic" (Colchester 2003, I93). However, rather than passively accepting her place and the place of other Polynesian women as exotic "Others" in a Western telling, Raymond has sought to challenge and change peoples' perceptions through the medium of the visual arts. Raymond outlined the significance of her goal: "I set out to find a way of reworking those images of 'the exotic dusky maiden.' She was part of our heritage after all. I wanted Pacific islanders to be able to reclaim her, to bring her back under our control" (Colchester 2003, I93).

One of the most spectacular examples of Raymond's reclaiming and reworking of the dusky maiden motif is the manipulated photograph, Full Tusk Maiden (figure 3), which she created in 1999 in collaboration with her photographer husband Kerry Brown when they moved to Britain.

The Full Tusk Maiden began as an alter-ego character that Raymond brought to life during artistic gigs in New Zealand. In the absence of such performance opportunities in Britain, Raymond decided to capture the character "in a visual art form" (Raymond, pers comm, 2007), offering an alternative view of the "dusky" muse.

The black-and-white photograph features the digitally manipulated image of Raymond dressed in material objects that signify strength in Polynesia, such as "pua seeds, boars' tusks" (Colchester 2003, 207). With both hands placed on her hips and legs spread wide, the Full Tusk Maiden assumes a powerful haka stance-a posture that in many Poly- 


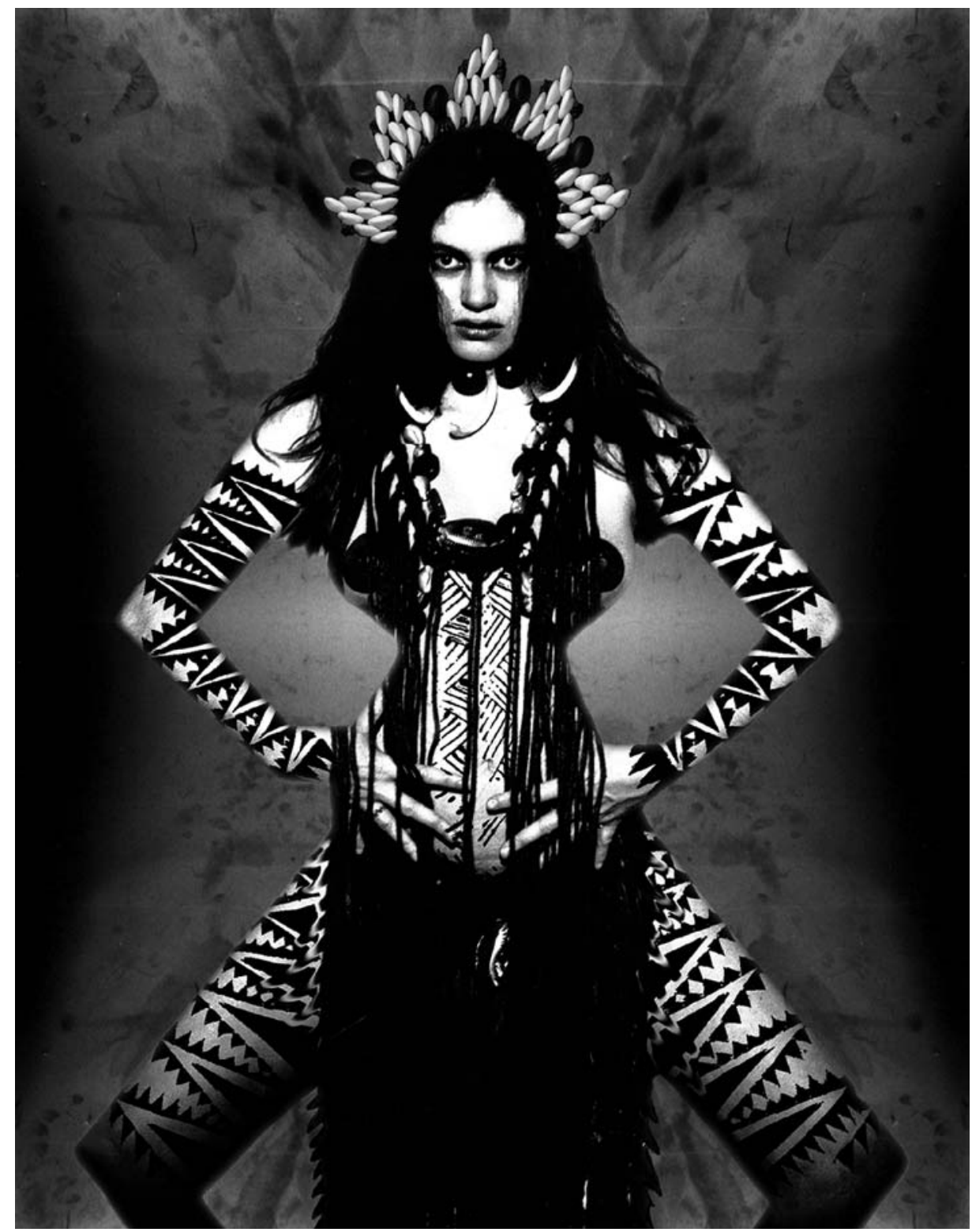

Figure 3 Full Tusk Maiden, Rosanna Raymond

Photography by Kerry Brown, concept and adornments by Rosanna Raymond, digital manipulation by Damon Mangos, I999, 7 I cm x $66 \mathrm{~cm}$. Courtesy of Rosanna Raymond. 
nesian cultures denotes defiance and strength. Digitally applied "tattoos" boldly cover her arms and legs, and her steady, penetrating gaze conveys in a potent way self-possession, self-sufficiency, and agency. The Full Tusk Maiden is not only beautiful-she is intimidating.

In a rather humorous way, Raymond's Full Tusk Maiden creation confounds the fanciful notions of eighteenth-century traveler Johann Reinhold Forster, who viewed Polynesian women, and specifically Tahitian women, as having "a beautifully proportioned shape, an irresistible smile, and eyes full of sweetness" (quoted in Jolly I997, 42I). Raymond's potent image denies all such flights of the Western imagination: her body, far from being "beautifully proportioned," is digitally mutated and comprises sharp angles and lines; her mouth is a grim line of defiance, and her eyes, far from being "full of sweetness," beckon the viewer to step closerif he dares. This is no submissive maiden-this is a cyber wahine with attitude!

While it may be tempting to view the Full Tusk Maiden as the antithesis of her "dusky" counterpart, it would be a mistake to conflate the two in a simplistic binary arrangement. To supply a more critical interpretation of the relationship between the dusky maiden and the Full Tusk Maiden, I invoke the nebulous realm of the wā (vā in Sāmoa), a liminal space that is marked by ambiguity and transformation. In Hawaiian culture, the wà represents not only the space between two objects, but also the space between two points in time (see Andrews 2003, 5II). Mary Kawena Pukui and Samuel Elbert extended the definition by stating that even the space between musical notes constitutes the wà (Pukui and Elbert I986). In his essay "Tatauing the Post-Colonial Body," Albert Wendt considered the significance of the wā/vā in Samoan culture in terms of human relations: "Important to the Samoan view of reality is the concept of Va or Wa in Maori and Japanese. Va is the space between, the betweenness, not empty space, not space that separates, but space that relates, that holds separate entities and things together in the Unity-that-is-All, the space that is context, giving meaning to things" (I999, 402; italics in original). The wā is thus a space of multiple meanings, a negotiable space where people or things can shift in any number of directions; it is, in short, a space of dynamic potential. In considering these important definitions relating to the wā, the relationship between the dusky maiden and her Full Tusk sibling is made more salient: rather than being polar opposites, they are instead two sides of the same coin, flipping back and forth through the transformative space of the wà when it suits them. In the following sec- 
tion, these shape-shifting qualities provide a critical basis for understanding Shigeyuki Kihara's work.

\section{Shigeyuki Kihara}

Shigeyuki Kihara is an artist of Samoan and Japanese descent. At the age of sixteen she immigrated to Aotearoa, and since receiving a diploma in fashion design and technology from Wellington Polytechnic, she has worked as a fashion stylist and multimedia artist in Aotearoa as well as abroad (Mallon and Pereira 2002). Indeed, in terms of global recognition of her work, Kihara has enjoyed considerable success. In October 2008 she became the first Pacific Islander artist to exhibit at the world-famous Metropolitan Museum of Art in New York (Tautai Newsletter 2008). Titled "Shigeyuki Kihara: Living Photographs," the exhibition featured fifteen of the artist's photographic creations, including Fa'a fafine: In the Manner of a Woman, a series of three photographs, discussed later. Like Rosanna Raymond, Kihara uses her own body to recast the dusky maiden motif and confront pervasive Western stereotypes of Polynesian women. Importantly, Kihara not only reoccupies the Polynesianist gaze, but as a transgender individual, she also challenges notions of gender and sexuality in her work. Cook Islander artist and curator Jim Vivieaere stated: "Kihara was born to defy categorisation. Her very existence blurs and challenges the organisation of mainstream thought and practice.... She has stood uncompromisingly in her own marginalised space, fully intending the world to come to her" (quoted in Message 2005, 5). Kihara, like the Dusky/Full Tusk Maiden, is a shape shifter, a liminal being who sabotages the expectations of the viewer.

Kihara made her debut in the New Zealand art scene in 2000 with "Teuanoa'i: Adorn to Excess," an exhibition that included twenty-eight T-shirts, each one lampooning a recognizable corporate logo. For example, one T-shirt parodies Barbie, that ubiquitous icon of Western beauty. However, using humor as a tool of subversion, Kihara has reworded the logo so that it instead reads "Fobie," a play on the acronym $F O B-$ Fresh Off the Boat-a tongue-in-cheek term referring to Pacific Island immigrants, specifically those from Sāmoa. In addition, a full-figured doll of cocoa-brown complexion (her brown-ness connecting her to the Pacific), replaces the otherwise recognizable figure of Barbie-white, slender, and blonde. Markers typically associated with the Pacific also accompany Kihara's Polynesian Barbie-she wears a cowry shell necklace, and two hibiscus flowers are incorporated into the "Fobie" logo. As Kylie Message 
has relayed, the central motivation behind Kihara's work in the "Adorn to Excess" exhibition was to relay to visitors the pervasiveness of cultural stereotypes and the force by which they are commodified and consumed in contemporary New Zealand society $(2005,6)$. Kihara's 2004 exhibition "Vava'u: Tales from Ancient Samoa" provided a critical counterpoint to the sexually charged velvet paintings of the I950s and I960s. In describing her work vis-à-vis the erotic trope of the velvet genre to $\mathrm{R}$ Hanson (2004), Kihara stated, "What I do is re-occupy that [colonial] gaze... I come from the point of view of the insider" (quoted in Message 2005, 4-5).

In her 2005 exhibition, "Fa'a fafine: In the Manner of a Woman," 9 Kihara employed mimesis to invert earlier representations of Polynesian women-here, Samoan women-that were rendered through the conventions of nineteenth-century Western photography (Message 2005, 5). In considering the use of photography to construct a sexualized image of Polynesian women for the consumption of male Western audiences, Caroline Vercoe stated, "Like many indigenous peoples, Pacific Islanders have been the subjects of innumerable photographic studies, ranging from medical to anthropological to touristic. To cater to the booming nineteenth-century postcard industry, a plethora of exoticised images were constructed and photographed" (quoted in Message 2005, I I). By creatively reenacting black-and-white nineteenth-century photographic representations of Samoan women, Kihara actively takes control of her own image, as well as that of the dusky maiden.

In the first image of her triptych series of sepia photographs titled $\mathrm{Fa}^{\prime} \mathrm{a}$ fafine: In the Manner of a Woman, I, 2, 3 (figure 4), Kihara is featured reclining on an antique chaise longue. In the top image, the only item of clothing she wears is a grass skirt; her breasts are bare. Kihara's long, dark tresses tumble over her shoulders as she stares enigmatically into the camera lens. The scenery behind her consists of props that were typically employed in nineteenth-century photographs as a means of evoking the exotic: tropical foliage and a woven mat. In the middle photograph, Kihara has removed the skirt, and languishes in complete nudity. To the unassuming viewer, she is for all intents and purposes the quintessential dusky maiden.

But the dusky maiden is difficult to pin down. She shifts shape when we are not looking. And so it is that Kihara transforms as the camera shutter opens and closes. In the bottom image, Kihara appears once again in sultry repose on the chaise longue; nothing in the scene has changed, bar the fact that she reveals an unexpected side of her identity: her phallus. 

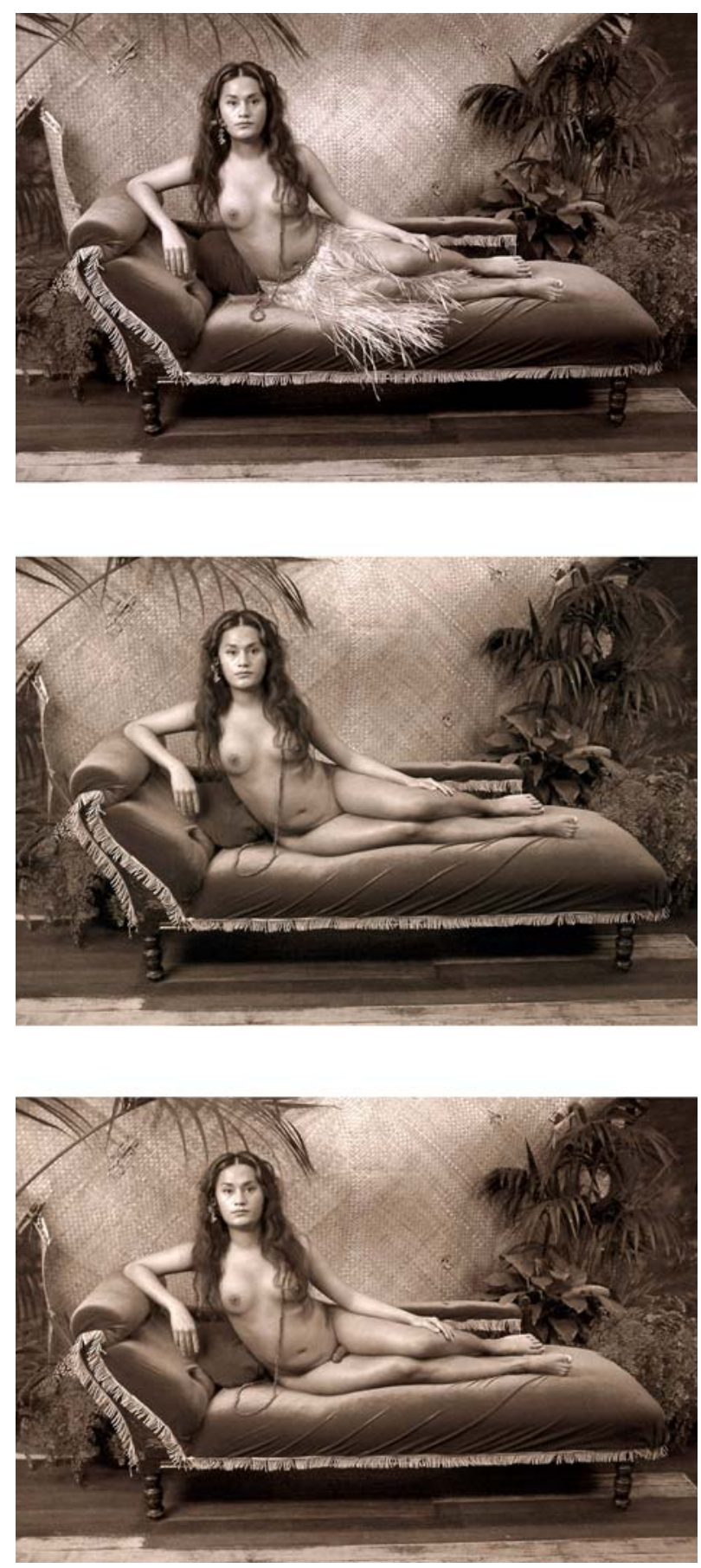

FIgURE $4 \mathrm{Fa}^{\prime}$ a fafine: In the Manner of a Woman, Shigeyuki Kihara. Photography and mixed media, 2005 , each image $60 \mathrm{~cm} \times 80 \mathrm{~cm}$. Edition $5+2 \mathrm{AP}$. Courtesy of artist Shigeyuki Kihara and photographer Sean Coyle. 
Here, Kihara uses her own body to simultaneously cross the boundaries of the colonial gaze as well as demolish the rigid binaries of gender as it is perceived in the Western world. As she recently noted, "my work and my existence as a Fa'a fafine goes against every thread which makes up the social fabric that is essentially palagi based. The $\mathrm{Fa}^{\text {'a }}$ fafine series both undermines and interrogates the scheme of western classification" (pers comm, May 2009). Kihara is the dusky maiden, but not as we imagine her. Vivieaere has stated: “There is a seriousness in Kihara's posturing that undermines the irony she may wish to invoke or the truth she wishes to declare-a sense of 'passing' as a woman or as a man impersonating a woman, against the woman who is a man impersonating a man" (quoted in Mok 2006, I05). By performing her own identities as a transgender individual, as one who physically embodies the liminal space of the wā, Kihara opens up new ways of viewing the dusky maiden that confound dominant masculinist and colonialist expectations.

In the previous two discussions, I have focused on the ways in which Raymond and Kihara have reinscribed the dusky maiden with new meaning through the use of their own bodies. In the final part of this section, I consider the work of Sue Pearson, a Norfolk Islander who uses images of her female ancestors, as well as traditional Tahitian and Pitcairn tapa designs, to confront and challenge the myths surrounding the Tahitian women of the Bounty.

\section{Sue Pearson}

New Zealand-based artist Sue Pearson is a direct descendant of the English men and Tahitian women of the Bounty, who founded a settlement on Pitcairn Island in 1790 after Fletcher Christian and his fellow mutineers overran the ship and set captain William Bligh and eighteen of his men adrift in the middle of the Pacific Ocean. Pearson's work is critically informed by her genealogical connections to the Bounty women, and she uses her creative practice as a vehicle through which to challenge and subvert the prevailing stereotypes that served to trivialize and objectify her female ancestors. ${ }^{10}$ Pearson has exhibited her work on her home island of Norfolk, ${ }^{11}$ as well as throughout the Pacific, Europe, and the United States. Pearson's creative repertoire comprises the mediums of photography, painting, and printmaking.

In July 2007, Pearson's work appeared at the Artstation Gallery in Auckland, New Zealand, alongside that of female artists from all over the world, in an exhibition titled "Pocahontas Meets Hello Kitty." The central 


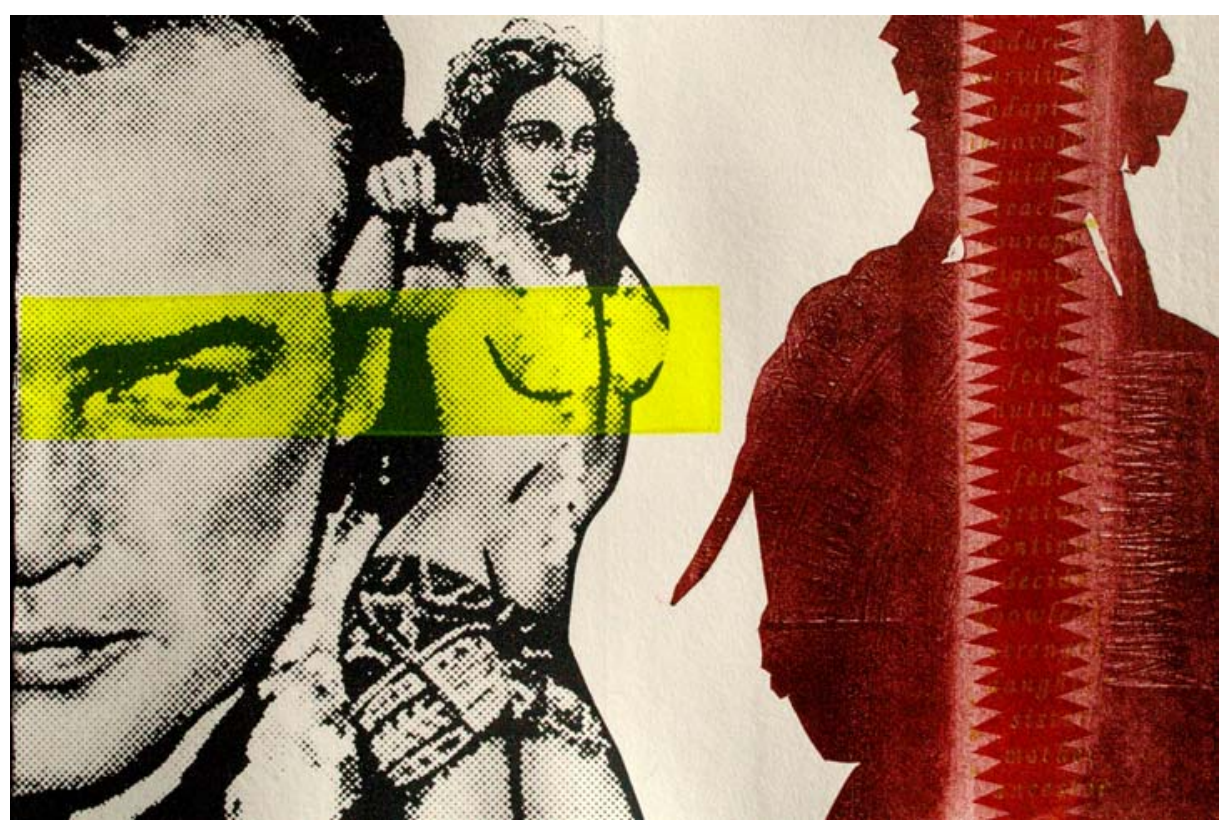

Figure 5 Whose Eyes Are You Looking Through? by Sue Pearson Screen print, $2005,27.9 \mathrm{~cm} \times 35.6 \mathrm{~cm}$. Courtesy of Sue Pearson.

goal of the exhibit was to challenge previous representations of indigenous women and replace them with new, more empowering images, from the viewpoint of native female artists.

Pearson's silk-screened print Whose Eyes Are You Looking Through? (figure 5), which appeared in the show, offers a critique of Hollywood's filmic depictions of her ancestors. In discussing her motivation for creating the piece, Pearson noted, "For a long time Hollywood images have been the only visual representation of my ancestors. ... I was trying to juxtapose the Hollywood version alongside a more realistic image of them" (pers comm, July 2007).

The cinematic portrayals of the Bounty women that Pearson seeks to challenge in her work are by no means new, and can be traced back to the early years of motion pictures. Beginning in I9 6 with the Australian-produced silent movie titled (rather predictably) The Mutiny on the Bounty, a total of five Bounty films have been produced (Dening I992). An inherent feature of all the films is their mythologization of the Bounty women as objects of colonial desire, behaving in ways that are both powerfully seductive and strikingly submissive. 
In her essay "Visual Pleasure and Narrative Cinema," Laura Mulvey interrogated the ways in which women are represented through cinema. She stated, "The determining male gaze projects its fantasy onto the female figure, which is styled accordingly. In their traditional exhibitionist role women are simultaneously looked at and displayed, with their appearance coded for strong visual and erotic impact" (Mulvey I989, I9). The I962 production of Mutiny on the Bounty (Milestone 1962), which Pearson alludes to in Whose Eyes, constitutes one of many filmic narratives in which Polynesian women, here the Tahitian women of the Bounty, are summarily reduced to objects of sex and pleasure in order to satiate Eurocentric male appetites.

One scene in the 1962 Bounty film depicts the ship's arrival in Tahiti. A wide-angle lens pans over a veritable sea of topless Tahitian women, each of whom, after scrambling from a canoe onto the ship's deck, falls into the arms of the first sailor she encounters. Delirious with lust after months at sea, the sailors grope their female consorts, who willingly oblige their advances. On land, lei-laden women dance provocatively for the newcomers, and then lead them into the dense tropical foliage where the Bounty men partake of the feminine bounty of the island. Later on, in the wake of the mutiny, the Tahitian women-who followed the rebels in their desperate dash to evade the British authorities-are portrayed as nothing more than voiceless, passive wards, dependent on the Bounty men for their survival in a foreign land.

In Whose Eyes Are You Looking Through? Pearson challenges viewers to critique the ways in which their understanding of the Bounty women has been shaped through such films as the 1962 cinematic narrative, and to recognize how those representations are a far cry from reality.

The left half of Pearson's print is dominated by two figures, Marlon Brando's Mutiny on the Bounty headshot, and a woman in archetypal dusky maiden pose-topless and wearing a pareu that threatens to slip from her waist, thereby revealing her nether regions. A horizontal streak of fluorescent yellow links Brando's line of sight to the woman's breasts. Brando's lustful sideways glance may be read as symbolic of the voyeuristic/fetishistic male gaze (Mulvey 1989). Significantly, Pearson has purposefully rendered Brando's image much larger than that of the young woman's. Here she points to the way in which indigenous women have been diminished to mere figures of entertainment on the silver screen, while, in contrast, their Western male counterparts have been aggrandized (pers comm, July 2007). 
In contrast, the right side of the print is dominated by the red silhouetted figure of a Pitcairn Islander named Hannah, who was a descendant of the Tahitian Bounty women. As Pearson stated: "I have used her image to represent us all, but particularly the original foremothers" (pers comm, August 2007). A Pitcairn Island tapa design runs down the center of this figure's spine, flanked by twenty-four words that describe Pearson's Tahitian ancestors. The words read as a genealogy of sorts, tracing the experiences, triumphs, and hardships of the women as they adjusted to life on Pitcairn Island. From top to bottom the words read as follows: sustain, endure, survive, adapt, innovate, guide, teach, courage, dignity, skill, cloth, feed, nurture, love, fear, grieve, continue, decided, knowledge, strength, daughter, sister, mother, ancestor.

Here Pearson is attempting to illuminate an alternative side to her ancestors. Despite being portrayed as passive agents in a male-dominated telling, the women of the Bounty (there were twelve) were anything but weak. ${ }^{12}$ As Pearson pointed out, "I was contrasting the 'babes on the beach' dusky maiden with women who suffered incredible hardship, who endured and survived, who nurtured their children in a strange land, who were incredibly strong and resourceful and who are our foremothers" (pers comm, July 2007).

Greg Dening also pointed to the agency of the Bounty women: "[They] made hideaways in the mountains, they captured muskets. They pulled the Bounty planks from the houses and made a boat or raft on which to escape. At times they made war on the men, who then had to conceal weapons in safe places to which they could retreat" (I992, 323). The Bounty women were also mothers, rearing and nurturing their children individually as well as collectively. They grew crops and "made the rhythm of every day" (Dening I992, 32I). When Captain Mayhew Folger discovered the Pitcairn settlement in 1808 , he found only one surviving male, John Adams. The other men who had landed on Pitcairn's shores in I790 (there had been fifteen in all, including the nine mutineers and six Tahitian men) had either been murdered or had died from disease or misadventure (Silverman 1967, 77). The rest of the population-thirty-five individuals-included the Tahitian women and their children (Silverman 1967, 92). Indeed, life on the island pivoted around the Bounty women; it was their resourcefulness and strength that ensured the survival of their children and the existence of future generations of Bounty descendants such as Sue Pearson. If the Bounty women symbolize female strength and perseverance, then Sue Pearson, who uses her creative practice to subvert 
the myths surrounding her female ancestors, is a living representative of their lasting legacy.

\section{Loosing the Dusky Maiden}

Over the last several years, Polynesian women have been recasting the dusky maiden in new and empowering ways. Indeed, in relation to the epigram at the beginning of this article, they have been bringing our imagination into clearer focus. Although this article has featured only three of those artists, there are countless others whose powerful works are creating critical spaces in which to view, in a more complex and nuanced way, Polynesian women and their Dusky Maiden sister. As Lisa Taouma has so astutely pointed out, it is through the work of these Polynesian female artists that "the 'dusky maiden' is finally allowed to 'look' herself" (2004, 45). Indeed, in answering Sue Pearson's question-Whose eyes are you looking through? - the resounding answer is: our own.

In writing this article, I have spent a considerable amount of time thinking about Poedua's portrait. I have found myself pondering who she might have been and what her experiences were like during her incarceration on Cook's ship. It is, of course, impossible to know the details of her life; her voice, like so many other indigenous voices from the early contact period, is absent from the Western narratives. We do know that within ten years of her portrait being painted, Poedua was dead, as indicated by Captain William Bligh during his anchorage in Tahiti in I788: "Poee-dooah of Ulietea [Ra'iatea], the Lady who Mr. Webber made a painting of, Odiddee told me was dead" (Bligh 1937,385 ). To locate Poedua, then, I attempt to reach beyond the veil by turning to the realm of fiction. In the last part of this article, I want to metaphorically peel back the painted layers of the young woman's portrait in order to reveal a different likeness-one that we may not be able to see with our eyes, but that we can nevertheless visualize through our collective imagination.

It was the first night of the full moon. Four days had passed since Cook and his men had taken Poedua and her male relatives captive on his ship. During that time, she had had to endure much, but worst of all was the stench of the English sailors, whose unwashed bodies gave off an odor that smelled worse than rotten fish. She longed to return to her mother 
and sisters, her aunts and grandmothers. She tried to conjure up the warm scent of the coconut oil she and her women folk used daily to rub into their skin and comb through their hair. She imagined the tiare bush, ${ }^{13}$ which grew behind her family's fare; ${ }^{14}$ in full bloom, each flower was a fragrant miracle. She breathed in the image, and then it was gone.

Standing on the ship's deck, Poedua closed her eyes and let the soft ocean breeze wash over her. The salt air was soothing, yet still she could not shake off the last vision she had had of her female kin as they stood on the beach cutting their heads and bodies, their powerful expression of grief a response to the knowledge that she was being taken from them. Even after Cook's ship had slipped over the horizon, she could still hear the women's high-pitched wailing-or had it been her own cries of terror and lamentation? She opened her eyes in panic: Blood, everywhere-in the water, covering their bodies, arms outstretched, mouths open. Poedua pulled in a deep breath to stem the tide of fear that was steadily engulfing her, held it for several seconds, and then exhaled slowly and evenly. Tilting her head up to the moon, she began to offer a chant to her ancestress 'Ere'erefenua ${ }^{15}$-Black Land-for liberation.

Black land, abundant land imprinted in memory, grooved into soul Black land, my land, turning into sea, into wind, into waves Black land, generous land, stretch your fertile body over me and remind me of my place in your secret crevices, your ever-changing form.

Black land, free me and fill me so that I may give myself back to you.

As the last note of her voice receded against the night, Poedua stopped to listen, hoping for a response from her ancestress. "I am here, daughter," she would say. "Where are your enemies? I will devour them with my obsidian vagina. I will crush them between my thighs until their eyes pop out and their tongues hang loose." But there came no such response. All Poedua could hear was the murmuring of the water as it gently lapped against the hull of the ship, and the scuttling and squeaking of rats as they made their nocturnal excursions around the deck in search of food. Her heart sank. Would it be so terrible to simply jump overboard into Taaroa's embrace? ${ }^{16}$ Then she heard something familiar. In the distance, the sound of . . . what? . . singing? No-her mind was playing tricks on her. The ship was miles from land. Not even the leeward wind was strong enough to carry voices this far over the water. But, there it was again. Yes! It was singing-soft, melodious, feminine. 
A cloud had eclipsed the moon and it was difficult for Poedua to locate the source of the voices. She peered hard into the inky blackness and saw what she thought were figures moving toward the ship. The singing became louder, and now she could hear the steady movement of paddles. As she leaned her body over the ship's railing to get a better view, the moon burst from behind the cloud, illuminating the surrounding ocean. And there, just off the starboard bow, were two canoe loads of women, their faces glowing radiantly as the light of the moon washed over them.

As the canoes came alongside the ship, one of the women hailed her. "Sister," she called. "Ere'erefenua, our mother, has sent us to free you. Climb down into this canoe. We must leave now." No sooner had the young woman finished speaking than Poedua spotted Cook, her captor, climbing up from the galley. Without thinking she leaped over the side of the ship into the water. As her head submerged, everything went black. She felt a force from below pulling her down. Taaroa wanted her for his own, she knew. But then she felt many hands take hold of her, pulling her up out of the water toward the refracted glow of the moon. It seemed as though the moon was using its own gravitational force to bring her to the surface. She fell into one of the canoes and immediately the women began paddling away from the ship.

Cook had seen Poedua jump overboard, and raised the alarm. "Capture that woman!" he bellowed, "I'll not have her escape!" After releasing two of the ship's tenders, Cook's men began pursuing the canoes. Poedua spoke: "Please, friends, what can we do? Their boats are swift, and they have many muskets. I fear you have placed yourselves in terrible danger for me." One of the women spoke: "Sister, we are women and we are resourceful. Look," she pointed astern of the canoe. Poedua turned expecting to see the tender nearly on them, but instead all she saw was mayhem. Someone had taken an axe to the hulls of the tenders, and now both were steadily sinking; the men bailed furiously, but to no avail. "Fire your arms!" yelled Cook. But there was only silence. "Sir," stuttered one of his lieutenants, "it would appear that all the muskets have been taken by the canoes yonder." "Then, make ready the sheets and come around. Let this ship apprehend them," came Cook's aggravated reply. But when the sails were dropped, Cook and his men saw that they had been torn to shreds. What was left floated like specters on the wind.

The women in the canoes began laughing riotously as they pointed to one of their group, a young woman, who stood in her canoe triumphantly brandishing an axe in one hand, a musket in another, and a knife between 
her teeth. Spitting out the knife, she yelled back to Cook and his men, "My tusks are full of your bounty, but it is the collective tusk that has torn you in two. You would do well to remember who we are. Let me introduce you to my siblings: Manatua, Toofaiti, Teraura, Opuole, Teio, Vahineatua, Faahotu, Tevarua, Teehuteatuaonoa, Mareva, Tinafornea, the Maiden of the Wā. As for myself, I am the Full Tusk Maiden." Poedua added quickly with her own voice: "And I am Poedua, daughter of "Ere'erefenua and sister of these women!" With that, the women raised their paddles, let out an exultant cry to the goddess that bound them together, and began to stroke-one, two, three-their voices lifting in song as the moon illuminated an ocean path for their journey home.

THIS ARTICLE BEGAN LIFE as a humble graduate paper while I was a student in the University of Hawai'i's Pacific Islands studies MA program. I am indebted to Vilsoni Hereniko for seeing the potential of that nascent work to be expanded into something of publishable substance, and for his constructive criticism and insight during the preliminary stages of its development. My thanks to Terence WesleySmith and David Hanlon for the sustained interest they showed as this article took shape and for encouraging me to take the final step toward submitting it for review. Much aroha to Carl Franklin Ka'aila'‘au Pao for his support as I labored over the writing of this piece. I am deeply appreciative of the helpful feedback I received from two reviewers, Karen Stevenson and Miriam Kahn. I am grateful to Karen Kosasa for her comments on an earlier draft of this paper as well as to Jan Rensel for her top-notch editorial assistance. Thanks to the National Library of Australia and the National Maritime Museum in London for permitting me to reproduce two of the images in their collections. Kia ora koutou ki ngā wāhine toa! Rosanna Raymond, Shigeyuki Kihara, and Sue Pearson: thank you for so generously allowing me to write about you and feature your incredible work in this article. Finally, my gratitude goes to Poedua, who was the initial inspiration behind this work, and whom I still think about during every full moon.

\section{Notes}

I I first came across this quote from Twain (I998, 346) in Lyons 2006.

2 Other artists included Daniel Dodd, Jean-Pierre Bérenger, and Giovanni Battista Cipriani.

3 I thank Robert Sullivan for this observation. 
4 Courtenay (sometimes spelled Courtnay) is quoted by Smith (I960, 32; emphasis in original).

5 Bougainville was the first Frenchman to arrive on the shores of Tahiti, in I768, a year after the British captain of the HMs Dolphin, Samuel Wallis, took possession of the island in honor of King George III of England. For an insightful discussion of the encounter between Tahitians and the British, see Dening 2000.

6 That the women in the boats were nude does not imply sexual hospitality. Rather, as Serge Tcherkézoff has pointed out, by exposing their bodies, the women believed they would "capture through impregnation, real or metaphorical" the apparent power of the newcomers $(2003,7 \mathrm{I})$.

7 Bougainville named Tahiti "New Cythera." Cythera refers to the mythical birthplace of the Greek goddess of love, Aphrodite (see Kahn 2003, 3 Io).

8 Other permutations of the young woman's name are Poedoua, Poydoa, Poyadua, and Poetua.

9 To view more images from "Fa'a fafine: In the Manner of a Woman," visit the Sherman Galleries Web site: http://www.shermangalleries.com.au/artists/ inartists/artist.asp? artist $=58$ \&exhibition $=90$

Io Pearson's specific ancestors include Teraura and Matthew Quintal, Vahineatua and John Adams, Mauatua and Fletcher Christian, and Eio and William McCoy.

I I In I 856 , all one hundred and ninety-four of the Bounty descendants relocated from Pitcairn Island to Norfolk Island.

I2 A total of twelve women-Mauatua, Toafaiti, Teraura, Obuarei, Vahineatua, Faahotu, Tevarua, Teehuteatuaonoa, Mareva, Tinafernea, Teio, and Teio's ten-month-old daughter, Sara-arrived on the rugged shores of Pitcairn Island in I790 (see Silverman I967, 50-52).

I3 Tiare is the gardenia plant.

I 4 A fare is a Tahitian residence. Other cognates of "fare" in Polynesia include whare, fale, and hale.

I 5 In the Tahitian cosmogony, the goddess 'Ere'erefenua was associated with war (see Craig 2004).

I6 Taaroa is the god of the sea in Polynesian mythology, also known as Ta'aroa, Tangaroa, Tagaloa, Tangaloa, and Kanaloa.

\section{References}

Andrews, Lorrin

2003 A Dictionary of the Hawaiian Language. Waipahu: Island Heritage Publishing.

Barnard, Alan

2000 History and Theory in Anthropology. Cambridge, uk: Cambridge University Press. 
Beaglehole, J C, editor

I967a The Journals of Captain James Cook on His Voyages of Discovery. The Voyage of the Resolution and Discovery 1776-I780. Part I. Cambridge, uk: Published for the Hakluyt Society at the Cambridge University Press.

I967b The Journals of Captain James Cook on His Voyages of Discovery. The Voyage of the Resolution and Discovery I776-I780. Part 2. Cambridge, uk: Published for the Hakluyt Society at the Cambridge University Press.

I969 The Journals of Captain James Cook on His Voyages of Discovery. Cambridge, uk: Published for the Hakluyt Society at the Cambridge University Press.

Beckwith, Martha

I976 Hawaiian Mythology. Honolulu: University of Hawai'i Press. Originally published by Yale University Press, I940.

Bindman, David

2004 "Philanthropy seems natural to mankind": Hodges and Captain Cook's Second Voyage to the South Seas. In William Hodges 1744-I797: The Art of Exploration, edited by Geoff Quilley and John Bonehill, 2 I-25. New Haven, ст: Yale University Press.

Bligh, William

I937 The Log of the Bounty: Being Lieutenant William Bligh's Log of the Proceedings of His Majesty's Armed Vessel Bounty in a Voyage to the South Seas, To Take the Breadfruit From the Society Islands to the West Indies. Volume I. London: Golden Cockerel Press.

Bougainville, Louis Antoine de

I967 A Voyage Round the World. Translated from the French by John Reinhold Forster. New York: Da Capo Press.

Çelik, Zeynep

I996 Colonialism, Orientalism, and the Canon. Art Bulletin 76 (2): 202205.

Colchester, Chloë

2003 Clothing the Pacific. New York: Berg.

Courtenay, John

I774 Epistle (Moral and Philosophical) from an Officer at Otaheite. London: Printed for T Evans.

Craig, Robert D

2004 Handbook of Polynesian Mythology. Santa Barbara, CA: AвC Clio.

Dening, Greg

I992 Mr Bligh's Bad Language: Passion, Power and Theatre on the Bounty. Cambridge, uk: Cambridge University Press. 
I997 Empowering Imaginations. The Contemporary Pacific 9 (2): 419-429.

2000 Possessing Tahiti. In Remembrance of Pacific Pasts: An Invitation to Remake History, edited by Robert Borofsky, I I 2-I32. Honolulu: University of Hawai'i Press.

Hanson, R

2004 Shigeyuki Kihara Re-occupies the Gaze. Posted on the Connecting the Pacific: Event Polynesia Web site, I 5 November. http://www .eventpolynesia.com/events/samoa/SA3_page_kihara.htm

Jolly, Margaret

I997 From Point Venus to Bali Ha'i: Eroticism and Exoticism in Representations of the Pacific. In Sites of Desire, Economics of Pleasure: Sexualities in Asia and the Pacific, edited by Lenore Manderson and Margaret Jolly, 99-I 22. Chicago: University of Chicago Press.

Kahn, Miriam

2003 Tahiti: The Ripples of a Myth on the Shores of the Imagination. History and Anthropology I4 (4): 307-326.

Kalākaua, David

I990 The Legends and Myths of Hawaii: The Fables and Folk-Lore of a Strange People. Honolulu; Mutual Publishing. First published in I 888 by Charles L Webster and Co, New York.

Kame'eleihiwa, Lilikalā

I999 Nā Wāhine Kapu: Divine Hawaiian Women. Honolulu: 'Ai Pōhaku Press.

King, Michael

I996 Maori: A Photographic and Social History. Revised edition. Auckland: Reed Books.

Lyons, Paul

2006 American Pacificism: Oceania in the US Imagination. New York: Routledge.

MacLean, Alistair

I972 Captain Cook. New York: Doubleday \& Company, Inc.

Mallon, Sean, and Pandora Fulimalo Pereira

2002 Pacific Art Niu Sila: The Pacific Dimension of Contemporary New Zealand Arts. Wellington: Museum of New Zealand Te Papa Tongarewa.

Mathews, Nancy Mowll

200I Paul Gauguin: An Erotic Life. New Haven, Ст: Yale University Press.

Meleiseā, Mālama

I999 The Postmodern Legacy of a Premodern Warrior Goddess in Modern Samoa. In Voyages and Beaches: Pacific Encounters, I769-I840, edited 
by Alex Colder, Jonathan Lamb, and Bridget Orr, 55-60. Honolulu: University of Hawai'i Press.

Message, Kylie

2005 Contemporary Identity, Culture and the Art of Redress: Tokyo Street Style and Shigeyuki Kihara in Aotearoa New Zealand. In "Asian" Media Arts Practice In/And Aotearoa New Zealand. Special issue of New Zealand Journal Of Media Studies 9 (I). Online at the New Zealand Electronic Text Centre http://www.nzetc.org/tm/scholarly/ tei-Scho9IJMS-tI-gI-t $3 . h t m l$ [accessed 28 July 2009]

Milestone, Louis, director

I962 Mutiny on the Bounty. Directed by Louis Milestone and produced by Aaron Rosenberg. I76 minutes. Metro-Goldwyn-Mayer. Videocassette.

Mok, Tze Ming, editor

2006 Fa'afafine: In the Manner of a Woman. Landfall 2I I (I): 97-I07.

Mulvey, Laura

I989 Visual Pleasure and Narrative Cinema. In Visual and Other Pleasures, I4-26. Bloomington: Indiana University Press.

O’Brien, Patty

2006 The Pacific Muse: Exotic Femininity and the Colonial Pacific. Seattle: University of Washington Press.

Orbell, Margaret

I999 The Illustrated Encyclopedia of Māori Myth and Legend. Christchurch: Canterbury University Press.

Pomare, Maui, and James Cowan

I987 Legends of the Maori. Volume I. Auckland: Southern Reprints.

Pukui, Mary Kawena, and Samuel H Elbert

I986 Hawaiian Dictionary. Revised and enlarged edition. Honolulu: University of Hawai'i Press.

Said, Edward W

I994 Orientalism. New York: Vintage Books. First published by Pantheon Books in 1978.

Schoeffel, Penelope

I987 Rank, Gender and Politics in Ancient Samoa: The Genealogy of Salamāsina O Le Tafaifā. Journal of Pacific History 22 (4): I74-I93.

Silverman, David

I967 Pitcairn Island. New York: The World Publishing Company.

Smith, Bernard

I960 European Vision and the South Pacific I768-1850: A Study in the History of Art and Ideas. London: Oxford University Press. 
1992 Imagining the Pacific: In the Wake of the Cook Voyages. Carlton, vic: Melbourne University Press.

Steubel, C

I976 Myths and Legends of Samoa: Tala O Le Vavau. Wellington: A J \& A W Reed.

Taouma, Lisa

2004 "Gauguin is Dead . . There is No Paradise." Journal of Intercultural Studies 25 (I): 35-46.

Tautai Contemporary Pacific Arts Trust Newsletter [Newton, Auckland, New Zealand]

2008 Shigeyuki Kihara. Tautai Contemporary Pacific Arts Trust Newsletter, September.

Tcherkézoff, Serge

2003 On Cloth, Gifts, and Nudity: Regarding Some European Misunderstandings During Early Encounters in Polynesia. In Clothing the Pacific, edited by Chloë Colchester, 5 I-75. New York: Berg.

Twain, Mark

I998 A Connecticut Yankee in King Arthur's Court. Oxford World's Classics. New York: Oxford University Press.

University of Cambridge

2007 Pacific Waves to Hit Cambridge. March 2007. University of Cambridge Web site http://www.admin.cam.ac.uk/news/press/dpp/2007032036 [accessed 26 August 2008]

Urale, Sima, director

I996 Velvet Dreams. Directed by Sima Urale and produced by Vincent Burke and Clifton May. 46 minutes. Top Shelf Productions. Videocassette.

Waldroup, Heather Leigh

2004 Traveling Images: Representations of the South Pacific from Colonial and Postcolonial Worlds. PhD dissertation, University of California, Santa Cruz.

Wendt, Albert

I999 Afterword: Tatauing the Post-Colonial Body. In Inside Out: Literature, Cultural Politics, and Identity in the New Pacific, edited by Vilsoni Hereniko and Rob Wilson, 399-4 I 2. Lanham, MD: Rowman \& Littlefield.

Yamauchi, Chikako

2005 Interview with Rosanna Raymond. Pacific News from Mānoa, October-December.

Yates-Smith, Aroha

I998 Hine! E Hine! Rediscovering the Feminine in Maori Spirituality. PhD dissertation, University of Waikato, Hamilton, New Zealand. 


\section{Abstract}

For centuries the image of the Dusky Maiden has occupied a prominent place in the Western imagination. Indeed, nowhere has it been so effectively shaped and deployed than through the visual arts. Portrayed as naive belles-cum-femme fatales through early Western paintings and later photographs, Polynesian women were presented to foreign audiences as symbols of the exotic, erotic, and dangerous. In the contemporary period, female Polynesian artists have sought to reconceptualize, challenge, subvert, and invert the image of their dusky maiden "sibling" in order to open up alternative spaces in which to reread this centuries-old icon. Here, I focus on the visual art creations of three women: Rosanna Raymond, Shigeyuki Kihara, and Sue Pearson, each of whom is actively engaged in reinscribing the stereotype of the Dusky Maiden with new and empowering meaning.

KeYwORDs: Dusky Maiden, goddesses, ancestresses, liminality, Polynesia, Polynesianism, visual arts 